\title{
URBAN SOLID WASTE TRANSPORTATION, COMPOSTING, RECYCLING, AND LANDFILL ISSUES IN SUBSAHARIAN AFRICA CITIES
}

\author{
Salimata Spinato ${ }^{1 *}$, Lydie S.A Yiougo ${ }^{2}$ and Michel Bues ${ }^{1}$ \\ ${ }^{1}$ University of Lorraine, CNRS, GeoRessources, F-54000 Nancy, France \\ ${ }^{2}$ Accounting school, Laval university, 418656 2131, Québec, Canada
}

Received 15 February 2021; received in revised form 16 August 2021; accepted 18 November 2021

\begin{abstract}
:
Developing countries struggle to manage their waste. These difficulties are linked to the lack of information on the quantitative and qualitative waste flows, the technical inadequacy of the organization of the collection, transport, recovery activities, and final disposal. This study aims to identify the factors limiting household solid waste management from collection to landfill and through the recovery stages in developing countries. The main activities included waste physical and chemical characterization. The study was conducted in Ouagadougou in Burkina Faso, Ségou, and Koulikoro in Mali and Kara in Togo. The characterization was based on the method called MODECOM (Method of household waste characterization, recommended by ADEME in France), followed by fines sampling of and their analysis in the laboratory. Analyses were carried out on crude fines and targeted chemical parameters such as hydrocarbons and heavy metals. Subsequently, leaching tests were carried out on the fines samples. The leachate analyzes included general parameters and heavy metal. Results show that the specific waste production is $0.75 \mathrm{~kg} / \mathrm{capita} /$ day in Ouagadougou, $0.43 \mathrm{~kg} / \mathrm{capita} /$ day in Koulikoro, and $0.39 \mathrm{~kg} / \mathrm{capita} /$ day in Kara. The fines constitute more than $20 \%$ of the total waste. Leachate heavy metal contents respect French standards. These results show the harmlessness of household waste in these cities, without mixing with wastes from semi-industrial and industrial activities.
\end{abstract}

Keywords: Solid Waste Management, Collection, Physical characteristic, Chemical characteristic, Optimization, Developing countries

(C) 2021 Journal of Urban and Environmental Engineering (JUEE). All rights reserved.

\footnotetext{
* Correspondence to: Salimata SPINATO, Tel.: +33667151937

E-mail: salimata.spinato@univ-lorraine.fr
} 


\section{INTRODUCTION}

High demographic and economic growth, urban expansion, and the increase of population living standards in Sub-Saharan Africa have had a significant impact on public health and solid waste management (SWM) services.

Pariatamby et al. (2019) raised a few difficulties for sustainable waste management in developing countries. Different authors like Medina, 1999; Achankeng, 2003; Troschinetz \& Mihelcic, 2009; Yiougo et al., 2013, likewise show that cities in African nations are faced with the management of large quantities of waste of different compositions with progressively heterogeneous and complex flows.

This situation is felt in the landscapes of most of the Sahelian countries, which are today marked by this issue of SWM with a helpless local population. We see increasingly more that the cultural character of their landscape appears to coordinate, even receive another face influenced by poor waste management.

In most urban areas, decentralization policy handovers on local communities the charge of waste management. Nonetheless, they are frequently faced with organizational problems, limited financial resources, and a lack or inadequacy of appropriate urban planning to waste management (Burnley, 2007a; Sujauddin et al., 2008).

This is the case of some municipalities that, despite having modern infrastructure to receive and recycle waste, are struggling to operate or monitor them due to a lack of qualified human resources. In some cases, once the infrastructures have been built, it can take a long time for the facilities to operate (instance of Sikasso in Mali). This facility was subsidized by Belgian cooperation in Mali for about 5.5 million euros, including $15 \%$ from the Malian State (Belgian Development Agency, (2017). This landfill remained unused for several years after its construction.

In different cases, private initiatives (NonGovernmental Organizations, Economic Interest Groups, community-based organizations.) and the informal sector attempt to contribute or provide their support to a population looking for a better living environment. In a few of these Sahelian countries, the informal sector assumes a significant role in waste recycling, which permits a few thousand people to ensure their subsistence through recycling activities (Wilson et al., 2006).

Guerrero et al. (2013) pointed out that waste management is a multi-factorial issue. Indeed, the author showed that waste management difficulty is not only related to technical issues yet additionally to environmental, socio-cultural, administrative, and financial factors. In some African mores and customs, the presence of waste in front of a concession was associated with lavishness and household food selfsufficiency ... This is no longer the case. Today, streets, sparsely inhabited spaces, and the outskirts of cities are generally used as a waste disposal area either clandestinely, through incivility, or in the absence of any rules governing waste management.

One of the critical challenges faced by solid waste management is the lack of waste flows knowledge, both quantitatively and qualitatively (Miezah et al., 2015). The predicted infrastructures with significant investments sometimes do not integrate wastes quantitative and qualitative nature. In most advanced countries in solid waste management, exact knowledge on the waste flows is one of the requirements for planning recovery and treatment facilities. This fact is a long way from being applied in the Sahelian countries. Characterizations showed that the inputs of the various flows include a lot of sand and/or rubble, generating significant transport costs. The large presence of this sand and additionally rubble likewise affects the fermentation cycle of buried waste. Sometimes before the final disposal, secondary collection and transport by donkey traction (cart) or by tricycle are inadequate, with very long routing and the presence of a large quantity of sand and rubble in these waste flows.

The population has faced different significant accidents: fire, waste avalanche ..., prompting serious consequences, because of poor waste management or a lack of specialized human resources.

This study aimed to identify the elements restricting SWM from collection to final disposal and recovery stages. It involved waste characterization in order to optimize recovery upstream of the landfill.

The methodology developed for waste flows knowledge is mainly based on waste physical and chemical characterization in four cities in Sub-Saharan Africa: Ouagadougou in Burkina Faso, Kara in Togo, Koulikoro, and Ségou in Mali. Only a chemical characterization was carried out on fines collected in Ségou. The paper presents the physical and chemical characteristics of wastes and highlights constraints faced by developing countries in SWM.

\section{MATERIAL AND METHODS}

The study was conducted in four cities in West Africa. The cities locations are shown in Fig. 1. Presentation of the studied cities. Ouagadougou, the capital of Burkina Faso, has a total area of $219 \mathrm{~km}^{2}$ and has almost 2.5 million inhabitants. The climate is Sudano-Sahelian with two seasons. A rainy season from June to September and a dry season from October to May. The average annual rainfall is $700 \mathrm{~mm}$. The average annual temperature is $28.2^{\circ} \mathrm{C}$. SWM is provided according to the city SWM master plan, drawn up in 2000 in partnership with the World Bank. The organization has three phases. The first stage comprises the precollection of household waste. The city of Ouagadougou is partitioned into twelve collection zones and has 45 transfer stations (TS). These collection zones are 


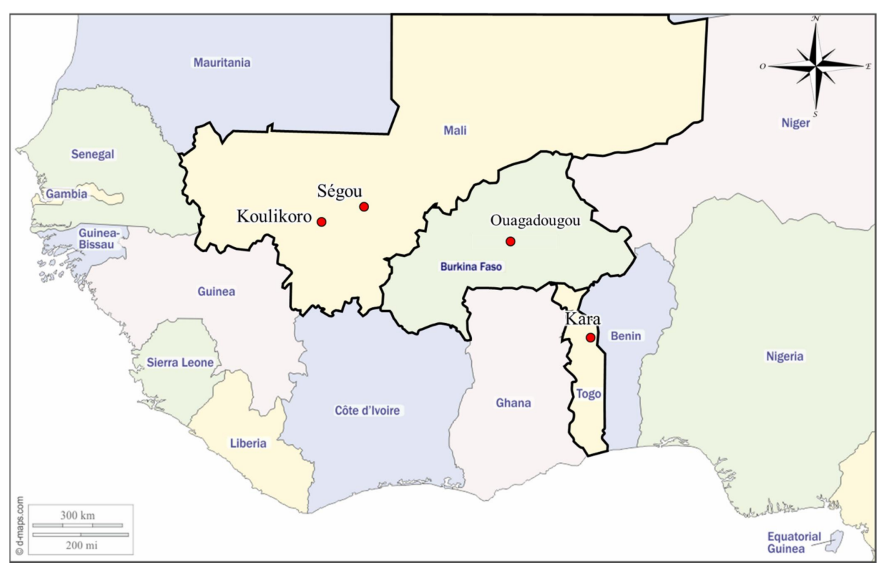

Fig. 1 Location of study cities.

granted by the municipality to the Economic Interest Groups (EIG) and Small and Medium-Sized Enterprises which are involved in door-to-door pre-collection (Mas \& Vogler, 2006).

The pre-collection is carried out by animal traction. Increasingly, however, pre-collection is carried out by mechanized means such as tricycles. Wastes are thus transported to transfer stations (TS). The second step is to collect and transport waste from the TS to the final disposal. Ouagadougou is subdivided into three zones for waste collection and transport. The municipality collects and transports the waste of two zones. The third is granted to a private (Mas \& Vogler, 2006). The last step is waste recovery and final disposal. Indeed, part of the waste is sorted at the TS. It includes plastic waste and cardboard boxes. This waste is stored. Sometimes, deals are made with specific purchasers or sent to Ghana. Composting and plastic recovery units are located at the landfill site. The composting unit has an annual production of 32.5 tons of compost. The one committed to the recovery of plastic waste produces 42 tons per year of shredded polypropylene, polyethylene, and polyvinyl chloride. The remaining waste stream is buried in the landfill with a capacity of 6.1 million $\mathrm{m}^{3}$ of waste.

Kara is the second biggest city in Togo and had 108 708 inhabitants in 2017. The city has a Sudanese to Sudano-Guinean tropical climate with a long rainy season from April to October and a dry season coinciding with the Harmattan winds between November and March. The annual average rainfall ranges between $1000 \mathrm{~mm}$ and $1800 \mathrm{~mm}$. The temperature varies between 16 and $39^{\circ} \mathrm{C}$ from January to December. The city of Kara does not have a SWM plan. Three intermediate dumps are summarily built to receive waste by voluntary contribution. This waste is collected and transported by a public operator to a "wild" landfill on the outskirts of the city. Three associations informally offer pre-collection services to households and administrative structures (Segbeaya, 2012).
Different efforts and initiatives exist, for example, the isolated activities of the municipality and the Water and Environmental Sciences Sanitation Laboratory (LASEE) of the University of Kara.

Koulikoro is located $60 \mathrm{~km}$ north-east of Bamako, the capital of Mali. The Koulikoro region is the second region of Mali which has nine sub-regions. The study occurred in the city of Koulikoro. The climate, Sudanese type, is described by a dry and wet season. The annual average temperatures shift somewhere in the range of 25 and $31^{\circ} \mathrm{C}$. The coldest period is between January and February. From March to May, the hottest period, temperatures reach $40^{\circ} \mathrm{C}$. The average annual rainfall is $855 \mathrm{~mm}$. The number of inhabitants in Koulikoro city was assessed at 52524 in 2016 with an annual growth rate of $3.8 \%$. The number of persons per household is assessed at 6 .

Regarding SWM, Koulikoro does not currently have a strategic plan. Consequently, despite the intervention of a few pre-collection actors, the city remains unhealthy. A study carried out in 2017 (DNACPN, 2017) reveals the presence of nearly 50 uncontrolled dumps in the city.

This study is part of the implementation of the national policy on environmental management and aims to develop a strategic plan for SWM for the city. So far, no organized SWM system exists.

The EIG "SANYA" for over a decade of existence remains operational, regardless of the difficulties. This EIG has contracts with a couple of households, especially in the army camp and some households from the downtown. The collected waste from households is discharged in fields or natural depressions. A landfill is planned to be built in Noumoubougou (Koulikoro subregion), about thirty kilometers from Koulikoro city. The expenses related to this facility to get waste from the capital (Bamako) are valued at 9.76 million euros (Daou Maliactu-net, 2015).

The fourth city covered by the study is Ségou. Ségou is the fourth administrative city in Mali, and the fifth city by its population of 200468 (INSTAT, 2011). The regional population is almost 2626500 . The city is located $240 \mathrm{~km}$ to the north-west of Bamako. It is situated on the right bank of the Niger River. The climate is the steppe type, with an average rainfall of $642 \mathrm{~mm}$ per year and an average temperature of $28^{\circ} \mathrm{C}$.

SWM system is obsolete and presents similar issues referenced above at Koulikoro. No development project committed to a waste facility is in progress.

Ségou was subdivided into neighborhoods, which are divided among EIG for SWM. These EIG, initially recognized by the municipality, were set up to guarantee solid waste primary collection. There is no municipal structure dedicated to SWM in Ségou, nor a private waste management system.

The EIGs ensure the primary collection (or precollection) of waste from door to door. They transport 
the collected waste to "transit stations" or final disposal. Seven transit stations had been created in Segou in 2010 but now, they were never built up.

But, nowadays, waste collection services are provided by informal operators. Their carts conducted by animal power (donkey) cover long distances to reach the locations defined as TS, or natural pits, creating "wild dumps" in different parts of the city. In Pélengana, one of the rural areas of Ségou, there has been a new EIG for two years. This EIG offers a primary collection from about 20 households. However, there is a lack of transfer stations or final disposal for the collected waste.

Physical characterization was not possible in Ségou, nor reliable data collection of waste collected quantity. An environmental analysis report on the urban environment led in 2011 by the World Bank, provides data on waste produced in Ségou. This project, PAPE/GTZ project, was held by the Ministry in charge of the Environment and Sanitation of Mali (World Bank, 2011). This report indicates an expected waste production of $259 \mathrm{~m}^{3} /$ day in Ségou from which $50 \%$ or $129.5 \mathrm{~m}^{3} /$ day is collected.

Apart from Ségou, all collected data reflect the current situation of the four cities. Particularly in Ouagadougou, two characterizations were completed. The analysis completed on the fines of the first characterization campaign indicated a significant level of heavy metals. Thus, a second campaign was completed in August 2019 by avoiding waste from automotorcycle garages. Indeed, during the first characterization campaign, the waste from a garage was collected and mixed with household waste. It is usual in the developing countries, during pre-collections, all wastes in a given zone are collected together without considering the nature of the waste and the activity of the producer.

\section{Sorting and characterization methods}

Waste characterization campaigns are based on MODECOM (Method of household waste characterization), developed by the French Environment and Energy Management Agency (ADEME), which proposes thirteen classes of waste (ADEME, 2006, 2014; Koledzi, 2015). MODECOM enabled to identify waste fractions and sub-fractions (Table 1), which have been adjusted to our context, i.e. eleven fractions of waste. Indeed, given the quantities found and the study objective, paper and cardboard were grouped into a single fraction, as textiles and sanitary textiles. This activity allowed us to identify the fractions and subfractions proposed by MODECOM. We have adapted according to the context, i.e. eleven fractions of waste.

As specified by the ADEME guide (ADEME, 2014), depending on the issues at stake, the precision of the characterization data can be very accurate (dimensioning of industrial installations) or a little less (argumentation of communication to a population for example). The weight of the primary sample for a characterization recommended in MODECOM is 500 $\mathrm{kg}$. In the four cities, in the absence of any weighing system in the sorting centers, two to four collection trips were selected for each characterization campaign.

In some cases, at the end of the characterization, and after weighing the fractions, that wastes quantity could exceed $500 \mathrm{~kg}$. As waste is collected door to door from households, the different flows from a routing are mixed before the sorting site. A subsequent mixing (turning) was completed during the unloading of the waste. The entire waste was sorted, classified by fraction, then weighed, and followed by fines sampling.

Ouagadougou is the best "location" for waste characterization compared to Ségou, Koulikoro and Kara because of the existing MSW organization. The sorting center was chosen in a joint effort with the municipal technical service in charge of SWM in Ouagadougou. This site gets waste from sector 22 of the city, which has quite the representativeness of "medium and low-income area" corresponding to the standard of living of most households in Ouagadougou. To know the number of households just as the number of persons per household subscribing to two pre-collection associations, a follow-up of pre-collection trips were completed. These two operators were followed during 4 days of pre-collection. The collected data allowed to estimate the specific production of the waste or waste generation rate is the waste quantity produced per person per day. Two waste pre-collection trips were characterized, namely the contents of a cart and the contents of a tricycle corresponding to the weekly production of 47 households. Sorting was carried out coarsely first on a plastic sheet, then a finer sorting on a sorting table to recover the fines (distance $\leq 20 \mathrm{~mm}$ ). The characterization occurred in September 2018, a second sample of fine material was taken in August 2019 (as referenced above, to eliminate waste from auto-motorcycle garages) and analyzed.

The organization of the characterization at Kara was somewhat different. Households were selected randomly according to different socio-economic standards of living, and on the condition that they uninhibitedly consent to take an interest in the investigation. In this way, three concessions were selected along the same street. Subsequently, two households at most are selected per concession, provided that each household has its garbage bin, and when the bin is common to the whole concession. All households are included for a maximum of four.

A sample of 72 households representing different types of socio-economic classes was selected. These households were given trash containers. Two characterization campaigns were completed, one in May 2018 and the second in June 2018. Three days of waste production were collected and transported using a tricycle to an intermediate landfill for waste sorting 
activities. The sorting material and equipment consist of a tarpaulin, a sorting table $(2 \mathrm{~m} * 1 \mathrm{~m})$ with two levels of sorting (diameters of 100 and $20 \mathrm{~mm}$ ), a scale, a sifter with a diameter of $20 \mathrm{~mm}$, bins, plastic bags, protective equipment (outfits, gloves, mufflers).

The characterization campaign in Koulikoro was done by collecting waste from 15 households in December 2019. Collection was completed by cart from door-to-door. A total of three collection trips were put together to have a representative sample. The sorting equipment comprises a plastic sheet, a scale, a sifter as well as protective equipment. There are no TS or structured facilities. To carry out the characterization, plastic sheeting was laid out on the floor. After sorting and weighing, the fines were sieved to recuperate the samples for chemical analyzes.

In Ségou, it was impossible to make a physical characterization because of the lack of a suitable structure or an organized system dedicated to SWM. The existing EIG is just in its earliest stages. Just a fines recovery campaign occurred in August 2019. For this purpose, wastes from twelve households were collected door-to-door and the fines recuperated after sieving. They were then analyzed in the lab, similarly as for Ouagadougou, Kara, and Koulikoro.

\section{Visual analysis}

Table 1 presents the different fractions and subfractions. In this study, as referenced above, the paper and cardboard were combined, forming one single fraction. Textiles and sanitary textiles also constitute one fraction. The different fractions were then weighed. The total weight was obtained by adding the weights of the different sorted fractions. This result was then divided by the average number of household members to obtain the waste production per capita (Rothenberger et al. 2006). The composition percentages of each fraction are calculated according to the following formula Eq.(1):

\section{Mass of the fraction of the category $\times 100$}

\section{Total mass of the deposit}

The specific production, namely the quantity of waste produced per person per day $(\mathrm{kg} /$ person/day) is calculated from the following relationship Eq. 2:

Mass of the total waste

$\mathrm{NoH} \times \mathrm{NoP} \times \mathrm{NoD}$
$\mathrm{NoH}$ : Number of Households

NoP : Number of people per household

NoD : Number of production days

Table 1. The different waste components considered during characterization according to MODECOM

\begin{tabular}{|c|c|c|}
\hline $\mathrm{N}^{\circ}$ & Fractions & Sub-fractions \\
\hline 1 & Organics waste & $\begin{array}{l}\text { Garden waste and kitchen } \\
\text { scraps }\end{array}$ \\
\hline 2 & Papers & $\begin{array}{l}\text { Packaging, Newspapers, } \\
\text { Magazines, and Others }\end{array}$ \\
\hline 3 & Cardboard & $\begin{array}{l}\text { Flat, corrugated and large } \\
\text { cardboard packaging }\end{array}$ \\
\hline 4 & Plastics & Soft and hard \\
\hline 5 & $\begin{array}{l}\text { No classified } \\
\text { combustible (NCC) }\end{array}$ & Wood, Leather, Charcoal \\
\hline 6 & $\begin{array}{l}\text { Incombustible no } \\
\text { classified (INC) or } \\
\text { inert }\end{array}$ & gravel and pebbles \\
\hline 7 & Textiles & Clothing \\
\hline 8 & Sanitary textiles & Baby diapers \\
\hline 9 & Metals & Ferrous and Non-ferrous \\
\hline 10 & Glasses & \\
\hline 11 & Special waste & Batteries and Chemicals \\
\hline 12 & $\begin{array}{l}\text { Composites or } \\
\text { miscellaneous }\end{array}$ & $\begin{array}{l}\text { Food packaging - milk, fruit } \\
\text { juice, coffee, butter }\end{array}$ \\
\hline 13 & Fines $<20 \mathrm{~mm}$ & Sands and ashes \\
\hline
\end{tabular}

\section{Samples Collection and fines preparation}

Fines sampling is done in a stock that has been mixed during the characterization and is based on manual methods (Fig. 2). Given the heterogeneity of the waste, the sampling was taken from passers-by (piles of fines) from the sorting table (or on piles directly for nonequipped zones) to acquire a representative sample of the concerned zone.

This method was inspired by the preparation methodology provided in the French standard NF EN 932-1 on the methods for taking aggregate samples. Automatic sampling can be used for fine material sampling. Given the local context, sampling was being made by manual methodology. Plastic sheeting was set below the sorting equipment (for cities with sorting tables available) or directly on the ground in cities where there is no equipment. Hence, sampling has been completed by considering: (a) the types of materials, (b) the size of the grains which constitute it, (c) the nature and weight to be sampled per bag, (d) local circumstances and (e) the objective of this study. 

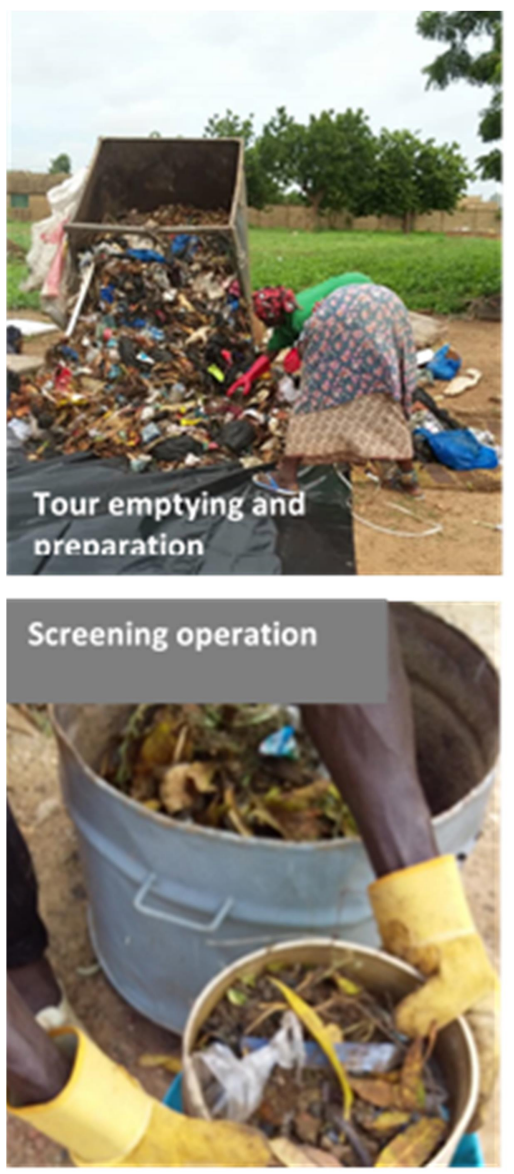
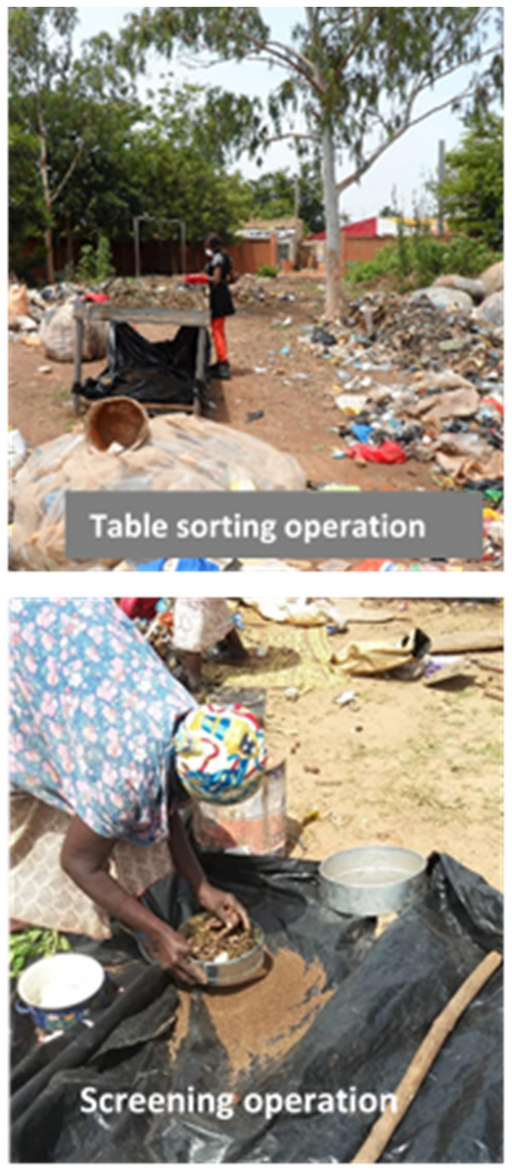

Fig. 2 Sorting and sampling activities
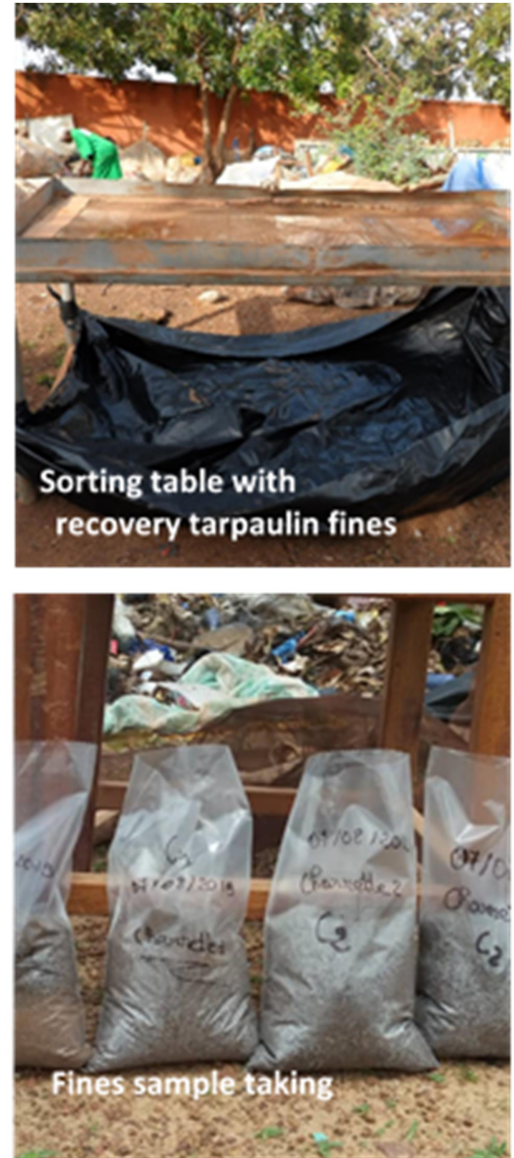

For each city, the weather conditions were favorable at the time of sampling (sunny, no precipitation and no wind). Each lot constituted after sieving was then reduced to obtain a sample of 2 to $5 \mathrm{~kg}$. The test catches, of the order of $1-1.5 \mathrm{~kg}$, were extracted after quartering and sent for chemical analysis.

\section{Laboratory analysis methods and associated standards}

The fines samples were analyzed in the lab at EUROFINS/LCDI - France, certified under number $\mathrm{N}^{\circ}$ 1-0965 by the French Accreditation Committee (COFRAC). The analyzes concerned mineral solids (raw samples) and general chemical parameters, Polycyclic Aromatic Hydrocarbons (PAHs), Polychlorinated biphenyls (PCBs), regulatory congeners, hydrocarbons, and the heavy metal content. Subsequently, the same laboratory carried out 24-hour leaching tests on the fines samples. The analyses on the leachate or eluate concerned the general parameters
( $\mathrm{pH}$, conductivity, TOC, etc.) as well as the content of heavy metals.

The test allowed us to comprehend the targeted parameters evolution in nature or in a landfill. Table 2 summarizes the analyzed parameters and the associated standards. This test aimed to acquire a cumulative release of concentration of parameters based on a liquidsolid ratio $(\mathrm{L} / \mathrm{S}=10 \mathrm{~L} / \mathrm{kg}$, i.e. $100 \mathrm{~g}$ of waste were put in one liter of water) with a granulometry $(G)$ less than $4 \mathrm{~mm}(\mathrm{G}<4 \mathrm{~mm})$ according to the French standard NF EN 12457-2. Table 2 presents the different parameters analyzed, the nature, and type of analyzes and the associated standards.

No regulations exist in the three countries to compare the obtained results with a threshold or criterion defining wastes classification. Thus, the results were compared with the standards establishing criteria and procedures for the acceptability of waste in landfills (inert, non-hazardous, and hazardous waste) in France and the European Directive for these types of waste. 
Table 2. Physico-chemical parameters analyzed on the samples of raw fines and eluates.

\begin{tabular}{|c|c|c|c|}
\hline & ANALYZES ON RAW SAMPLES & $\begin{array}{l}\text { ANALYZES ON } \\
\text { ELUATE (Leaching) }\end{array}$ & Analysis methods \\
\hline $\begin{array}{l}\text { General } \\
\text { parameters }\end{array}$ & $\begin{array}{l}\text { Total Organic Carbon (TOC), } \\
\text { Phenol index, Soluble fluoride, } \\
\text { Soluble chloride, Soluble sulphate } \\
\left(\mathrm{SO}_{4}\right)\end{array}$ & $\begin{array}{l}\mathrm{pH} \text {, Conductivity at } 25^{\circ} \\
\mathrm{C} \text {, Dry matter at } 105^{\circ} \mathrm{C} \\
\text { (Soluble fraction), Total } \\
\text { organic carbon (TOC), } \\
\text { Phenol number, Chlorides } \\
\text { [Cl-], Sulfates }\left[\mathrm{SO}_{4}{ }^{2-}\right], \\
\text { Fluorides (F-) }\end{array}$ & $\begin{array}{l}\text { NF ISO } 10694 \\
\text { NF EN ISO } 14402 \\
\text { NF T 90-004 } \\
\text { Spectrometry (UV / VIS) - NF } \\
\text { ISO 15923-1 }\end{array}$ \\
\hline $\begin{array}{l}\text { Polycyclic } \\
\text { Aromatic } \\
\text { Hydrocarbons } \\
16 \text { PAHs defined by } \\
\text { US-EPA* }\end{array}$ & $\begin{array}{l}\text { Acenaphthene, Acenaphthylene, } \\
\text { Anthracene, Benzo (a) anthracene, } \\
\text { Benzo (a) pyrene, Benzo (b) } \\
\text { fluoranthene, Benzo (ghi) perylene, } \\
\text { Benzo (k) fluoranthene, Chrysene, } \\
\text { Dibenzo (ah) anthracene, } \\
\text { Fluoranthene, Fluorene, Indeno } \\
\text { (1,2,3-cd) pyrene, Naphthalene, } \\
\text { Phenanthrene, Pyrene }\end{array}$ & & $\begin{array}{l}\text { GC / MS / MS [Hexane / } \\
\text { Acetone Extraction] - } \\
\text { NF ISO } 18287 \text { (soils) and XP } \\
\text { X 33-12 standard (mud, } \\
\text { sediment) }\end{array}$ \\
\hline $\begin{array}{l}\text { PCB regulatory } \\
\text { congeners }\end{array}$ & $\begin{array}{l}\text { PCB 101, РCB 118, PCB 138, PCB } \\
153, \text { PCB 180, РCB 28, РCB } 52\end{array}$ & & $\begin{array}{l}\text { GC / MS / MS [Hexane / } \\
\text { Acetone Extraction] - NF EN } \\
16167 \text { (Soils) } \\
\text { and standard XP X 33-12 } \\
\text { (mud, sediment) }\end{array}$ \\
\hline $\begin{array}{l}\text { Hydrocarbon } \\
\text { content }\end{array}$ & $\begin{array}{l}\text { Hydrocarbon index (C10-C40), HCT } \\
\text { (nC10-nC16), HCT (>C16-nC22), } \\
\text { HCT (>C22-nC30), HCT (>nC30- } \\
\text { nC40), Benzene, Ethylbenzene, } \\
\text { Toluene, m + p-Xylene, o-Xylene }\end{array}$ & & $\begin{array}{l}\text { GC / FID [Hexane / Acetone } \\
\text { Extraction] - NF EN } 16703 \\
\text { (Soils) } \\
\text { and NF EN } 14039 \text { (mud) NF } \\
\text { EN ISO } 22155 \text { (soil) or } \\
\text { Internal method (sludge, } \\
\text { sedimentation,) }\end{array}$ \\
\hline Heavy metals) & $\begin{array}{l}\text { Arsenic (As), Cadmium }(\mathrm{Cd}) \text {, } \\
\text { Chromium }(\mathrm{Cr}) \text {, Copper }(\mathrm{Cu}), \\
\text { Nickel }(\mathrm{Ni}), \text { Lead }(\mathrm{Pb}), \mathrm{Zinc}(\mathrm{Zn}) \text {, } \\
\text { Mercury }(\mathrm{Hg})\end{array}$ & $\begin{array}{l}\text { Mercury }(\mathrm{Hg}), \text { Arsenic } \\
(\mathrm{As}), \text { Barium, }(\mathrm{Ba}), \\
\text { Chromium }(\mathrm{Cr}), \text { Copper } \\
(\mathrm{Cu}), \text { Nickel }(\mathrm{Ni}), \text { Lead } \\
(\mathrm{Pb}), \text { Zinc }(\mathrm{Zn}), \text { Antimony } \\
(\mathrm{Sb}), \text { Cadmium }(\mathrm{Cd}), \\
\text { Molybdenum (Mo), } \\
\text { Selenium (Se) }\end{array}$ & NF EN 16192 \\
\hline
\end{tabular}

* The 16 PAHs ranked by the United States Environmental Protection Agency (EPA) on its list of priority pollutants

\section{RESULTS}

\section{Waste generation rate}

Waste generation rate found in Ouagadougou is 0.75 $\mathrm{kg} /$ person/day, $0.39 \mathrm{~kg} /$ individual/day in Kara, and 0.43 $\mathrm{kg} /$ individual/day in Koulikoro. The characterizations in Ouagadougou and Kara occurred during the rainy season corresponding to a high waste generation by households (presence of a large quantity of green waste). Other authors (Tezanou, 2003, Nshimirimana, 2010; Ouédraogo, 2010) gave a waste generation rate, ranging from 0.33 to $0.85 \mathrm{~kg} /$ individual/day for Ouagadougou depending on the season. The specific waste generation obtained in Ouagadougou fits well with values found in other cities of similar size, for example, Yaoundé, Brazzaville, Conakry, Accra, and Kumasi (Achankeng, 2003; Miezah et al., 2015; Ngnikam et al., 2017). The Average annual production of these cities varies between 0.6 and 0.75 $\mathrm{kg} /$ person/day. However, few studies have been done on waste in Kara. Maléki et al. (2018) found an annual average value of $0.41 \mathrm{~kg} /$ person/day in Kara. Characterization studies led in Togo, within the framework of a European Union project, give 0.44 $\mathrm{kg} /$ person/day in Atakpamé and $0.37 \mathrm{~kg} /$ person/day in Dapaong (IGIP, 2018). Thus, the value found in Kara compares well to the waste generation rate in the medium-sized towns of Togo. In the case of Koulikoro in Mali, the study on the collection and treatment of wastewater and solid waste (DNACPN, 2017) gives a specific production of $0.47 \mathrm{~kg} /$ person /day in 2016 against $0.43 \mathrm{~kg} /$ person /day found in the present study. Ségou's waste generation rate was estimated based on data from the previously mentioned national report on the environment in 2005. According to this report, the household waste generation rate is $259 \mathrm{~m}^{3} /$ day in Ségou. Based on an annual growth rate of $3.6 \%$ and a waste density of $300 \mathrm{~kg} / \mathrm{m}^{3}$ (INSTAT, 2011; Ngnikam et al., 
2017), the waste generation rate in Ségou is $0,39 \mathrm{~kg}$ /person/day. This assessed value is similar to that of Kara in Togo and Alkalakla in Sudan with a specific generation rate of $0.40 \mathrm{~kg}$ per person per day and a population of 245,000 inhabitants comparable to that of Ségou (Abdelgadir et al., 2019).

\section{Waste physical composition}

Household waste was sorted into 11 fractions as mentioned in the methodology. The percentages of each fraction are shown in Figs. 3-5. Presented waste fractions identified the recoverable and non-recoverable parts. The highest proportions are the fermentable parts such as kitchen leftovers and green waste, i.e. $35 \%$ in Ouagadougou and $23 \%$ in Kara. The fines constitute the largest proportion of waste in Koulikoro at 39\%.

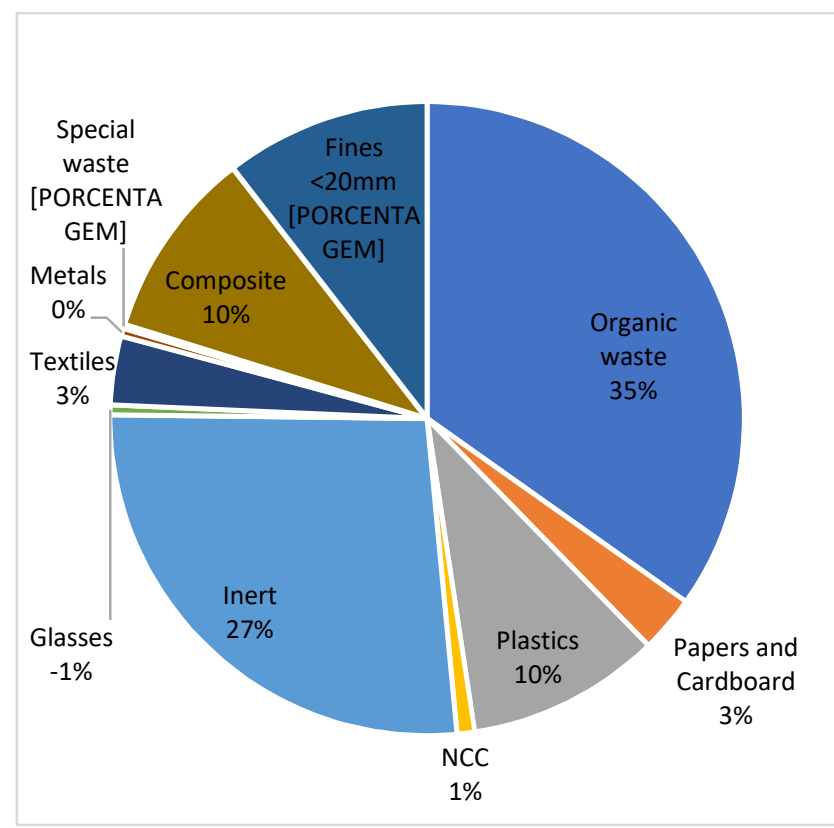

Fig. 3 Waste compositions in Ouagadougou

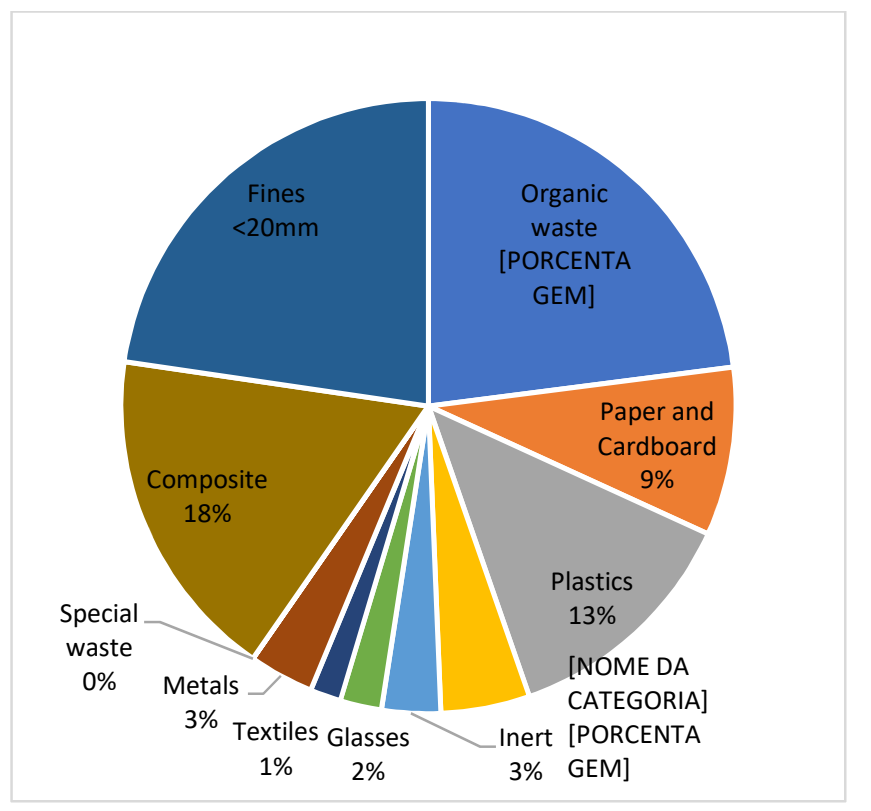

Fig. 4 Waste compositions in Kara

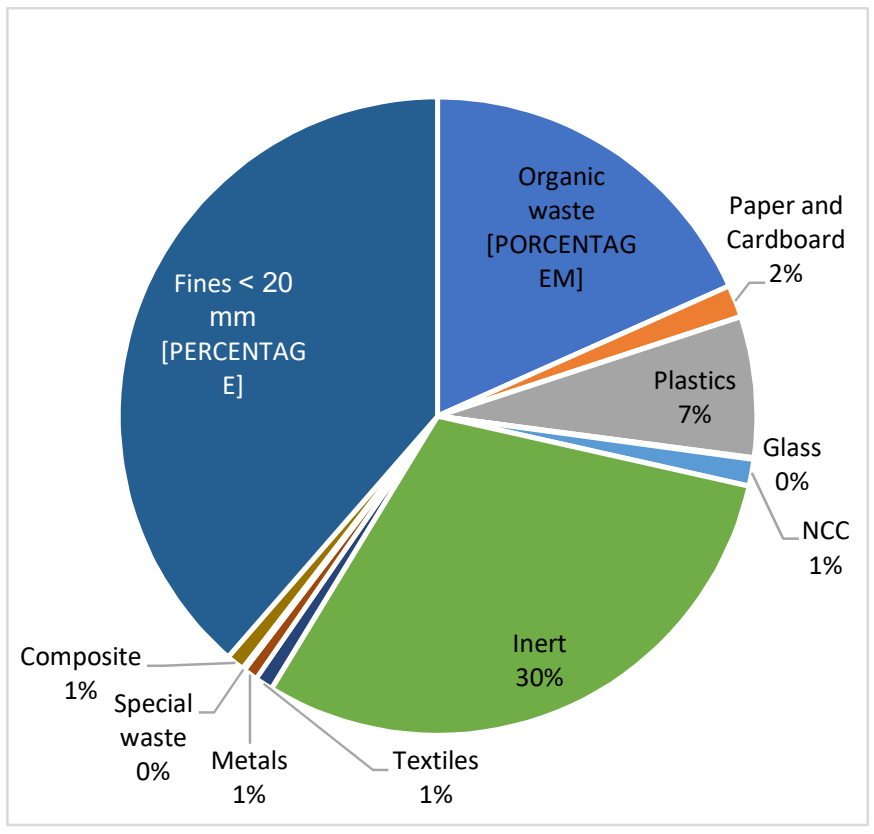

Fig. 5 Waste compositions in Koulikoro

In Ouagadougou, organic waste is followed by inert materials, fines, plastics, composites, textiles, paper, and cardboard, metals, and at last special waste. These outcomes are confirmed by different authors who have worked on waste characterization in Ouagadougou. Indeed, their results show that organic waste fraction ranging from 20 to $40 \%$ (Tezanou, 2003, Mien, 2009, Nshimirimana, 2010, Ouédraogo, 2010, Haro et al., 2018). Inert materials (rubble and stones) represent $27 \%$, and fines materials $10 \%$. However, by adding inert fraction to fines, $40 \%$ is obtained, which is close to the rate of Koulikoro.

Thus, without sorting, out of the 625 tons of waste collected and transported every day in Ouagadougou, nearly 232 tons are fines and rubble, i.e. $37 \%$ of the tonnage collected (almost 85,000 tons per year) which are transported in the landfill.

Plastics (hard and soft) represent $10 \%$ of waste (including $2 \%$ hard plastics) against $11 \%$ obtained by Haro et al. (2018) and 11\% obtained by Tezanou (2003) and Mien (2009). Paper and cardboard constitute 3\% and corroborate the same value found by Nshimirimana (2010). Haro et al. (2018) found a 6.4\% fraction of paper/cardboard in household waste.

Other components, such as metals, NCC, and special wastes are present to a lesser fraction. Composite corresponds to sorting refusal. In Kara, organic waste is followed by fines $(23 \%)$, composite $(18 \%)$, plastics (13\%), paper and cardboard (9\%), inert materials (5\%), NCC (5\%), metals (3\%) and textiles (1\%). Special wastes are found in insignificant quantities, i.e. $0.4 \mathrm{~kg}$ in the whole deposit of nearly one ton. For Kara, Maléki et al. (2018) obtained during characterization a greater fraction of fines $(42.7 \%)$ followed by inert $(26.8 \%)$ and organic waste (11.8\%). 
The present characterization results give $26 \%$ fines and rubble. Considering the annual waste generation of Kara (42 tons of waste), more than 10 tons cannot be recovered. In Koulikoro, fine materials are followed by INC at $30 \%$ and organic waste at $18 \%$. Plastics comprise $7 \%$ of waste, paper, and cardboard represent only $2 \%$. Given the lack of organization and structures dedicated to waste, it was not possible to carry out a physical characterization in Ségou.

\section{Waste chemical composition}

Few studies have been completed on the physicochemical composition of household waste in developing countries. Most analyzes completed on waste in the literature are focused on energy recovery. The parameters analyzed are then waste calorific value, the rate of ash, and volatile matter content (Kuleape et al., 2014, Haro et al., 2018). Some chemical analyzes have been done on the leachate and concern the Chemical Oxygen Demand (COD), the Biochemical Oxygen Demand (BOD5) analysis, and phosphorus and nitrogen pollution (Topanou et al., 2011). Most studies focus on waste physical characteristics.

Table 3 presents the results of the chemical analysis of raw fines samples. Without standards characterizing the kinds of waste in these three countries, the results were compared with the decree of December 12, 2014, identifying the conditions of acceptability of inert waste in France. Except for Ségou, the organic carbon content exceeds the limit values, for example, $79,200 \mathrm{mg} / \mathrm{kg}$ DM (Dry Matter) in Kara, 89,500 mg/kg DM, 30,400 $\mathrm{mg} / \mathrm{kg} \mathrm{DM}$ in Ouagadougou, and $55,800 \mathrm{mg} / \mathrm{kg} \mathrm{DM}$ in Koulikoro. The limit is $30,000 \mathrm{mg} / \mathrm{kg} \mathrm{DM}$ set by the previously mentioned decree in France. Without regulatory standards or leachate treatment (treatment plant), TOC reduction will remain essential before any release into the natural environment.

The rest of the other general chemical parameters show values below the threshold values. The sixteen PAHs classified as priorities for waste pollution as well as PCBs are found in minor components. However, the hydrocarbon index in Ouagadougou of fines from the first sampling campaign is higher than the inert limit, i.e. $790 \mathrm{mg} / \mathrm{kg} \mathrm{DM}$ instead of $500 \mathrm{mg} / \mathrm{kg} \mathrm{DM}$ of the standard.

This fact is due to the collection of waste from a car repair garage with household waste. During the second fines collection campaign, an arrangement was made to guarantee that waste from garages and other semiindustrial units were not collected and mixed with household waste. Hence the hydrocarbon content obtained was below the norm, i.e. $470 \mathrm{mg} / \mathrm{kg}$ DM. In comparison, the data are also lower than those found by a study carried out in the UK on municipal waste. Indeed, this study (Burnley, 2007b) gives heavy metal contents in fine material higher than the values found in Ouagadougou, Kara, Ségou and, Koulikoro, i.e., As of $16 \mathrm{mg} / \mathrm{kg}, \mathrm{Cd}$ of $1 \mathrm{mg} / \mathrm{kg}, \mathrm{Cr}$ of $97 \mathrm{mg} / \mathrm{kg}, \mathrm{Hg}$ of 0.2 $\mathrm{mg} / \mathrm{kg}$ and $\mathrm{Pb}$ of $706 \mathrm{mg} / \mathrm{kg}$. The values found in the UK on As are almost six times and the $\mathrm{Pb}$ eighteen times higher than the values found in the three cities.

Table 4 shows the results of the physicochemical analysis carried out on the eluates and Fig. 6 shows a comparison of the eluate's content heavy metal in the four cities compared to French standards.

Table 3. Results of chemical analyzes of raw fines samples

\begin{tabular}{|c|c|c|c|c|c|c|}
\hline & \multicolumn{5}{|c|}{$\begin{array}{l}\text { Comparison of different parameters in the three cities } \\
\qquad(\mathrm{mg} / \mathrm{kg} \text { M.S.) }\end{array}$} & \multirow{2}{*}{$\begin{array}{c}\text { Inert } \\
\text { (France } \\
\text { threshold) }\end{array}$} \\
\hline & Kara & Ouaga $^{1}$ & Ouaga $^{2}$ & Ségou & Koulikoro & \\
\hline \multicolumn{7}{|c|}{ General chemical parameters } \\
\hline Total Organic Carbon (TOC) & 79200 & 85900 & 30400 & 16100 & 55800 & 30000 \\
\hline Phenol index & $<0.50$ & $<0.50$ & 1.93 & $<0.50$ & $<0.50$ & \\
\hline Soluble fluoride & $<20.0$ & $<20.0$ & $<20.0$ & $<20.0$ & $<20.0$ & \\
\hline Soluble chloride & 401 & 434 & 693 & 701 & 857 & \\
\hline Sulfate soluble $\left(\mathrm{SO}_{4}\right)$ & 559 & 338 & 806 & 1390 & 421 & \\
\hline \multicolumn{7}{|c|}{ Polycyclic Aromatic Hydrocarbons (16 PAHs) } \\
\hline Acenaphthene & $<0.05$ & $<0.05$ & $<0.05$ & $<0.05$ & $<0.05$ & \\
\hline Acenaphthylene & $<0.05$ & $<0.05$ & $<0.05$ & $<0.05$ & $<0.05$ & \\
\hline Anthracene & $<0.05$ & $<0.05$ & $<0.05$ & $<0.05$ & $<0.05$ & \\
\hline Benzo(a)anthracene & $<0.05$ & $<0.05$ & $<0.05$ & $<0.05$ & $<0.05$ & \\
\hline Benzo(a)pyrene & 0.071 & $<0.05$ & $<0.05$ & $<0.05$ & $<0.05$ & \\
\hline Benzo(b)fluoranthene & 0.11 & $<0.05$ & $<0.05$ & 0.066 & $<0.05$ & \\
\hline Benzo(ghi)pérylene & 0.084 & $<0.05$ & $<0.05$ & $<0.05$ & $<0.05$ & \\
\hline Benzo(k)fluoranthene & $<0.05$ & $<0.05$ & $<0.05$ & $<0.05$ & $<0.05$ & \\
\hline Chrysene & $<0.05$ & $<0.05$ & $<0.05$ & $<0.05$ & $<0.05$ & \\
\hline Dibenzo (ah) anthracene & $<0.05$ & $<0.05$ & $<0.05$ & $<0.05$ & $<0.05$ & \\
\hline Fluoranthene & $<0.05$ & $<0.05$ & $<0.05$ & $<0.05$ & $<0.05$ & \\
\hline Fluorene & $<0.05$ & $<0.05$ & $<0.05$ & $<0.05$ & $<0.05$ & \\
\hline
\end{tabular}




\begin{tabular}{|c|c|c|c|c|c|c|}
\hline Indeno (1,2,3-cd) pyrene & 0.086 & $<0.05$ & $<0.05$ & $<0.05$ & $<0.05$ & \\
\hline Naphtalene & $<0.05$ & $<0.05$ & $<0.05$ & $<0.05$ & $<0.05$ & \\
\hline Phénanthrene & $<0.05$ & $<0.05$ & $<0.05$ & $<0.05$ & $<0.05$ & \\
\hline Pyrene & $<0.05$ & $<0.05$ & $<0.05$ & $<0.05$ & $<0.05$ & \\
\hline Sum of 16 PAHs & 0.35 & $<0.05$ & $<0.05$ & 0.066 & $<0.05$ & 50 \\
\hline \multicolumn{7}{|c|}{ PCB regulatory congeners } \\
\hline PCB 101 & $\begin{array}{c}<0.01 \\
0\end{array}$ & $<0.010$ & $<0.010$ & $<0.010$ & $<0.010$ & \\
\hline PCB 118 & $\begin{array}{c}<0.01 \\
0\end{array}$ & $<0.010$ & $<0.010$ & $<0.010$ & $<0.010$ & \\
\hline PCB 138 & $\begin{array}{c}<0.01 \\
0\end{array}$ & $<0.010$ & $<0.010$ & $<0.010$ & $<0.010$ & \\
\hline PCB 153 & $\begin{array}{c}<0.01 \\
0\end{array}$ & $<0.010$ & $<0.010$ & $<0.010$ & $<0.010$ & \\
\hline PCB 180 & $\begin{array}{c}<0.01 \\
0\end{array}$ & $<0.010$ & $<0.010$ & $<0.010$ & $<0.010$ & \\
\hline PCB 28 & $\begin{array}{c}<0.01 \\
0\end{array}$ & $<0.010$ & $<0.010$ & $<0.010$ & $<0.010$ & \\
\hline PCB 52 & $\begin{array}{c}<0.01 \\
0\end{array}$ & $<0.010$ & $<0.010$ & $<0.010$ & $<0.010$ & \\
\hline Sum of PCBs & $\begin{array}{c}<0.01 \\
0\end{array}$ & $<0.010$ & $<0.010$ & $<0.010$ & $<0.010$ & 1 \\
\hline \multicolumn{7}{|c|}{ Hydrocarbon content (C10-C40) -LS919 } \\
\hline Hydrocarbon index (C10-C40) & 190 & 790 & 470 & 190 & 160 & 500 \\
\hline $\mathrm{HCT}(\mathrm{nC} 10-\mathrm{nC} 16)$ & 14 & 22 & 7.4 & 4.1 & 15 & \\
\hline $\mathrm{HCT}(>\mathrm{C} 16-\mathrm{nC} 22)$ & 21 & 89 & 210 & 36 & 24 & \\
\hline $\mathrm{HCT}(>\mathrm{C} 22-\mathrm{nC} 30)$ & 59 & 300 & 93 & 50 & 48 & \\
\hline $\mathrm{HCT}(>\mathrm{nC} 30-\mathrm{nC} 40)$ & 98 & 370 & 160 & 100 & 72 & \\
\hline Benzene & 0.11 & 0.14 & $<0.05$ & $<0.05$ & $<0.05$ & \\
\hline Ethylbenzene & $<0.05$ & 0.22 & $<0.05$ & $<0.05$ & $<0.05$ & \\
\hline Toluene & 0.12 & 0.22 & $<0.05$ & $<0.05$ & 0.07 & \\
\hline $\mathrm{m}+\mathrm{p}-\mathrm{Xylene}$ & 0.05 & 0.15 & $<0.05$ & $<0.05$ & $<0.05$ & \\
\hline o-Xylene & $<0.05$ & 0.07 & $<0.05$ & $<0.05$ & $<0.05$ & \\
\hline Sum of BTEX & 0.280 & 0.8 & $<0.05$ & $<0.05$ & 0.07 & 6 \\
\hline \multicolumn{7}{|l|}{ Heavy metals } \\
\hline Arsenic (As) & 2.75 & 2.75 & $<1.00$ & $<1$ & 2.14 & \\
\hline Cadmium (Cd) & $<0.40$ & 0.60 & $<0.40$ & $<0.40$ & $<0.40$ & \\
\hline Chromium (Cr) & 23.9 & 51.8 & 42.6 & 24.2 & 27.8 & \\
\hline Copper $(\mathrm{Cu})$ & 32.7 & 38.9 & 17.6 & 19.7 & 18.9 & \\
\hline Nickel (Ni) & 12 & 11.5 & 7.29 & 5.53 & 7.12 & \\
\hline Lead $(\mathrm{Pb})$ & 34.7 & 38.2 & 11.4 & 20.3 & 9.49 & \\
\hline Zinc (Zn) & 274 & 370 & 153 & 102 & 144 & \\
\hline Mercury (Hg) & 0.44 & 0.32 & $<0.10$ & $<0.10$ & $<0.10$ & \\
\hline
\end{tabular}

NB: ${ }^{1}$ : sample from September $2018,^{2}$ : August sample 2019 
Table 4. Results of chemical analyzes on the eluate after the leaching tests

\begin{tabular}{|c|c|c|c|c|c|c|c|}
\hline & Kara & Ouaga $^{1}$ & Ouaga $^{2}$ & Ségou & Koulikoro & Units & $\begin{array}{c}\text { Inert } \\
\text { (France limit) }\end{array}$ \\
\hline $\mathrm{pH}\left(19^{\circ} \mathrm{C}\right)$ & 9.6 & 8.9 & 8.3 & 9.5 & 9.8 & & \\
\hline $\begin{array}{l}\text { Conductivity corrected } \\
\text { automatically at } 25^{\circ} \mathrm{C}\end{array}$ & 657 & 669 & 827 & 1010 & 1140 & $\mu \mathrm{S} / \mathrm{cm}$ & \\
\hline Dry residue at $105^{\circ} \mathrm{C}$ & 10500 & 12300 & 8540 & 15100 & 12000 & $\mathrm{mg} / \mathrm{kg} \mathrm{MS}$ & 4000 \\
\hline $\begin{array}{l}\text { Dry residue at } 105^{\circ} \mathrm{C} \\
\text { (Calculation) }\end{array}$ & 1.1 & 1.2 & 0.9 & 1.5 & 1.2 & $\% \mathrm{MS}$ & \\
\hline $\begin{array}{l}\text { Total organic carbon } \\
\text { (TOC) by oxidation }\end{array}$ & 240 & 580 & 430 & 840 & 1800 & $\mathrm{mg} / \mathrm{kg} \mathrm{MS}$ & 500 \\
\hline Phenol index on eluate & $<0.50$ & $<0.50$ & $<0.50$ & $<0.50$ & $<0.50$ & $\mathrm{mg} / \mathrm{kg} \mathrm{MS}$ & 1 \\
\hline Chlorides [Cl-] & 426 & 508 & 754 & 616 & 624 & $\mathrm{mg} / \mathrm{kg} \mathrm{MS}$ & 800 \\
\hline Sulphates [SO42-] & 601 & 345 & 628 & 1080 & 584 & $\mathrm{mg} / \mathrm{kg} \mathrm{MS}$ & 1000 \\
\hline Fluorides (F-) & $<5.00$ & $<5.00$ & $<5.00$ & $<5.00$ & $<5.00$ & $\mathrm{mg} / \mathrm{kg} \mathrm{MS}$ & 10 \\
\hline Mercury (Hg) & 0.003 & $<0.001$ & $<0.001$ & $<0.001$ & $<0.001$ & $\mathrm{mg} / \mathrm{kg} \mathrm{MS}$ & 0.01 \\
\hline Arsenic (As) & $<0.20$ & $<0.20$ & $<0.20$ & $<0.20$ & $<0.20$ & $\mathrm{mg} / \mathrm{kg} \mathrm{MS}$ & 0.5 \\
\hline Barium (Ba) & 1.4 & 10.9 & 1.17 & 3.04 & 0.93 & $\mathrm{mg} / \mathrm{kg} \mathrm{MS}$ & 20 \\
\hline Chromium (Cr) & $<0.10$ & $<0.10$ & 0.17 & $<0.10$ & $<0.10$ & $\mathrm{mg} / \mathrm{kg} \mathrm{MS}$ & 0.5 \\
\hline Copper $(\mathrm{Cu})$ & 0.2 & 1.2 & 1.43 & 1.41 & 0.85 & $\mathrm{mg} / \mathrm{kg} \mathrm{MS}$ & 2 \\
\hline Nickel (Ni) & $<0.10$ & 0.26 & 0.16 & 0.48 & 0.18 & $\mathrm{mg} / \mathrm{kg} \mathrm{MS}$ & 0.4 \\
\hline Lead $(\mathrm{Pb})$ & 0.15 & 0.86 & $<0.10$ & 0.21 & $<0.10$ & $\mathrm{mg} / \mathrm{kg} \mathrm{MS}$ & 0.5 \\
\hline Zinc (Zn) & 1.79 & 12.3 & 1.53 & 2.88 & 0.98 & $\mathrm{mg} / \mathrm{kg} \mathrm{MS}$ & 4 \\
\hline Antimony $(\mathrm{Sb})$ & 0.015 & 0.019 & 0.021 & 0.08 & 0.027 & $\mathrm{mg} / \mathrm{kg} \mathrm{MS}$ & 0.06 \\
\hline Cadmium (Cd) & 0.002 & 0.011 & 0.002 & 0.012 & 0.002 & $\mathrm{mg} / \mathrm{kg} \mathrm{MS}$ & 0.04 \\
\hline Molybdenum (Mo) & 0.031 & 0.066 & 0.137 & 0.159 & 0.0078 & $\mathrm{mg} / \mathrm{kg} \mathrm{MS}$ & 0.5 \\
\hline Selenium (Se) & $<0.01$ & $<0.01$ & $<0.01$ & $<0.01$ & $<0.10$ & $\mathrm{mg} / \mathrm{kg} \mathrm{MS}$ & 0.1 \\
\hline
\end{tabular}

NB: ${ }^{1}$ : September sample $2018,{ }^{2}:$ August sample 2019

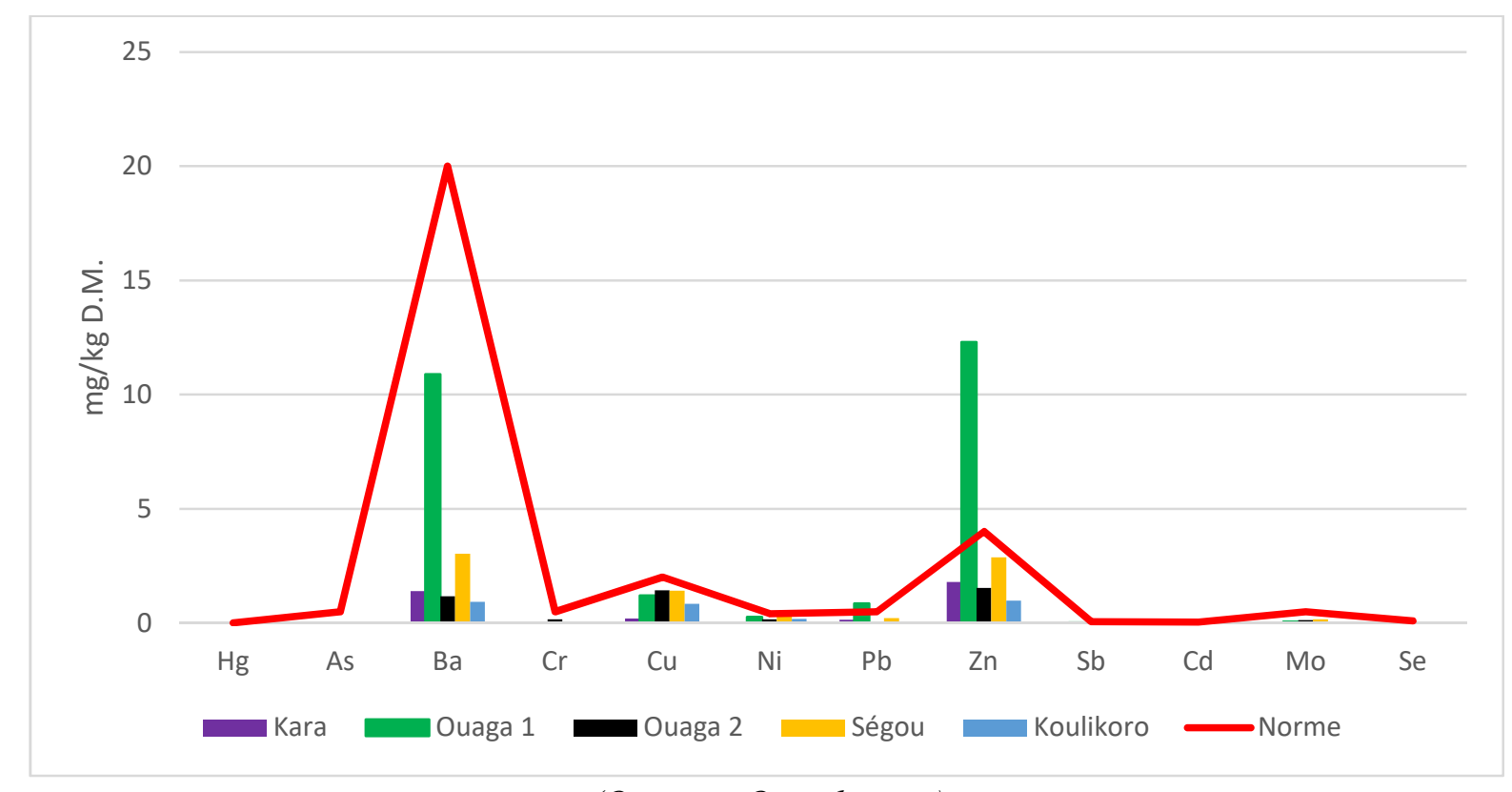

(Ouaga = Ougadougou)

Fig. 6 Content of the eluate of fines in Heavy metal of the Ouagadougou, Kara, Ségou, and Koulikoro waste and the limit values of French standards. 
The $\mathrm{pH}$ measured on the eluate of the fines from the four cities is basic (9.6 in Kara, 8.9 - 8.3 in Ouagadougou, 9.5 in Ségou, and 9.8 in Koulikoro). The basic character of the leachate is confirmed by several studies where the $\mathrm{pH}$ measured on the leachate is 8.9 in Ouagadougou (Demakoye et al., 2017), somewhere in the range of 8.33 and 8.78 in Abidjan (Naminata et al., 2018), 10 in Yaoundé (Oben et al., 2019), 8.24 in Alexandria in Egypt (Raghab et al., 2013), somewhere in the range of 7.6 and 8.5 in Ireland (Brennan et al., 2016). The TOC content is higher than the French standard in the four cities. For heavy metal, only the lead content exceeds the limit in the first sample in Ouagadougou. The lead content of the second sample respects the limit (a value of less than 0.1). The limit value is $0.5 \mathrm{mg} / \mathrm{kg}$ D.M. Other chemical analyzes should be done on the fine material to consolidate these results. An integrated SWM during pre-collection (by nature and or by type of activity) would strongly contribute to avoid heavy metal's significant presence in the waste, confirmed in Ouagadougou through the two characterization campaigns.

\section{DISCUSSIONS}

\section{Constraints related to wastes pre-collection, collection, and transportation}

Physical characterization of waste indicates fine materials ranging from $26 \%$ and $39 \%$ of the waste in Kara, Koulikoro, and Ouagadougou. Given similar habits and lifestyles in Ségou, the same percentage can be expected during a physical characterization of waste. This high content of fine material, gravel, and rubble can be explained by the sweeping method and the configuration of the majority of houses yards (gardens). Most houses have courtyards made of beaten earth, not covered with paving stones. This situation results in the transportation of over $20 \%$ of waste, composed of fine material and rubble, and has the consequence of reducing landfill lifespan. The proportion of such sand and/or rubble reaches $69 \%$ in Koulikoro in Mali. This extra transport involves very costly expenses for municipalities faced technical, material, and financial deficiencies.

These situations, coupled with the configuration of certain collection routings, the topography in some cases, the collected wastes are abandoned by the operators in natural depressions, rainwater networks, etc. In Yaoundé, the percentage of fine material constitutes $12.40 \%$ of the waste (Ngnikam et al., 2017). A characterization carried out in Abomey Calavi in Benin shows that over $20 \%$ of waste is represented by fine material (Topanou et al., 2011; Yamadje et al., 2013), confirming the significant presence of fine material in waste in Sahelian Africa. Another study carried out in Bembéréké in Benin, Kimana in Burundi, Gombé, and Kimbanseke in Congo DRC gives an average annual composition of nearly $34 \%$ of fine material and rubble contained in the waste (Ngahane et al., 2015). The expenses related to pre-collection, collection, and transport will remain high if actions are not taken upstream by households to reduce and limit the mass of sand and rubble in the waste.

\section{Constraints of composting and recycling activities}

This study showed that $35 \% \quad(23 \%$ and $18 \%$ respectively) of the waste comprises organic waste, therefore recoverable through a composting process in Ouagadougou, Kara, and Koulikoro. The other recoverable or recyclable components, composed of plastics, paper/cardboard, glasses, and metals, represent respectively $13.7 \%$ of waste in Ouagadougou, $27.2 \%$ of waste in Kara, and $9.6 \%$ in Koulikoro. Thus, almost $50 \%$ of waste can be recovered either by composting or by recovery in Ouagadougou and Kara; only $28 \%$ of waste is recoverable in Koulikoro. The literature review also shows that the average got for recoverable or recyclable components excluding organic waste in Bembéréké in Benin, Kimana in Burundi, Gombé, and Kimbanseke in Congo DRC was $5 \%, 15.7 \%$ in Cotonou, 6, 13\% in Abomey Calavi in Benin. This proportion reached $21.3 \%$ in Yaoundé in Cameroon and $25 \%$ on Average in Ghana (Tchakpa et al., 2013; Yamadje et al., 2013; Miezah et al., 2015; Ngahane et al., 2015; Ngnikam et al., 2017).

As a rule, recycling material reached $24 \%$ in cities of developing countries in Africa (Bundhoo, 2018). A good potential exists. However, without sorting at the source, the fines are intermingled with organic waste and other waste components. Thus, plastic and paper/cardboard are soiled by the waste juices and are therefore difficult to recycle. Sorting at source is even complex by the lack of separate collection and transportation. Glass and metals are commonly recovered at the source by pre-collection operators, or by "rag pickers" who sometimes go from door to door to collect this waste. The second obstacle to recovery activities is the time and human resources required for sorting. For instance, for the characterization in Ouagadougou, a total of $1,604 \mathrm{~kg}$ of waste was sorted. The entirety of the characterization activities (sorting and weighing) by the 20 sorters lasted 6.5 hours. The sorting output was then $12 \mathrm{~kg} /$ hour per sorter. Considering a daily production of Ouagadougou at $822 \mathrm{t}$ and an 8-hour working per day, a total of almost 8,561 sorters will be required. The collection rate is assessed at $76 \%$, so almost 6,500 sorters will be required every day. The current municipality budget dedicated to 
sanitation will not be able to support such an expenditure. Likewise, without source sorting, recovery/recycling activities are restricted. These difficulties are accentuated by the lack of outlets for recovered paper/cardboard and plastics which accumulate in sorting centers such as Ouagadougou, with fire hazards. Despite the ban on packaging legislated by many African countries, few manage to apply it like Rwanda (Adebiyi-Abiola et al., 2019). There are a few initiatives to promote plastics use, for example, the production of paving stone in Ouagadougou. But this activity is confronted with the lack of control of the manufacturing process (sand dosage, temperature stabilization ...), and few or no studies have been made on the consequences of the use of this kind of paving stones in the long term.

\section{Landfill optimization (need or not for a waterproof barrier given the chemical composition of the waste)}

Few cities in West Africa have a landfill. Some of them include Ouagadougou in Burkina Faso, Lomé in Togo, Dakar in Senegal, Abidjan in Côte d'Ivoire (Bundhoo, 2018). We can refer to the landfill of Sikasso in Mali, granted by the Belgian Technical Cooperation. These landfills were designed according to international standards by installing waterproofing barriers made of clay and geomembrane. As indicated by Thonart et al. (2005), the clay barrier, composed of natural clay and swelling clay (e.g. bentonite), should have a minimum thickness of $1 \mathrm{~m}$ with a penetrability coefficient of 10-9 $\mathrm{m} / \mathrm{s}$. This barrier is completed by a geomembrane with a minimum thickness of $2 \mathrm{~mm}$ in high-density polyethylene and treated against UV radiation degradation.

In France, for disposal facilities devoted to household and similar waste, i.e. non-hazardous waste, the requirements for the sealing, drainage, and the stability system require a passive geological barrier composed of in-situ subsoil (bottom and side) secured by an additional system that acts as an active barrier. Both of these barriers (passive and active) must meet well-defined standards to guarantee soil and water resource protection. For the active barrier, the bottom of the landfill cell must be designed from top to bottom with a layer which permeability is less than or equal to $1.10-9 \mathrm{~m} / \mathrm{s}$ over at least 1 meter thick and a layer which permeability is less than or equal to $1.10-6 \mathrm{~m} / \mathrm{s}$ over at least 5 meters thick. The sides of cells should have a permeability less than or equal to $1.10-9 \mathrm{~m} / \mathrm{s}$ over at least 1 meter thick, then comes the active barrier (geomembrane, geotextile, and so on).

To protect the geomembrane, materials, such as geotextiles and geocomposites are set between the geomembrane and the waste. These sealing barriers are intended to protect soil and water resources from pollutants. The leachate from household waste landfills carries several types of pollution, the most feared is heavy metals. To avoid the pollution caused by leachate, a leachate recovery and treatment system is installed. The installation of waterproof barriers and leachate recovery and treatment systems can cost several million euros. For instance, Ouagadougou's landfill costs more than 5 million euros. Considering the cost of these facilities, and the technicality of operating them, integrated management aimed at better waste collection remains necessary.

Physical and chemical analyses of the fines, as well as leaching tests, indicate for household waste produced in Ouagadougou, Kara, Koulikoro, and Ségou low levels of pollutants such as hydrocarbons and heavy metal. So given these results, devoting such heavy investments to waterproofing storage centers is not relevant in developing countries. Moreover, the presence of plastic waste slows down waste decomposition and leads to resurgence phenomena. As a result, rainwater remains under the plastic and therefore does not infiltrate by capillary action. The leachate recovery system, including pumping, therefore, remains non-functional after two to four years of use of the landfill.

In other cases, the emptying system does not have an unloading dock, so direct access to the traps by the collection equipment damages the sealing and drainage system. Tsuma et al. (2016); Naminata et al (2018); Ololade et al. (2019), through studies completed in Africa, show significant levels of heavy metals in leachate or in groundwater resources around landfills exceeding WHO standards in Abidjan, Nigeria, Kenya, and Ghana. This situation can be imputed to the collection of household waste joined with industrial waste which is practiced by a few African cities.

\section{CONCLUSION}

In conclusion, this study has identified the various challenges faced by cities in Sub-Saharan African countries concerning SWM. The first challenge is the collection and transport of nearly $20 \%$ of waste represented by fines and rubble prompting extra transport costs. The second challenge concerns waste recovery. Undoubtedly, without the effective implementation of a source sorting and separate collection, waste recovery efforts are undermined. Recoverable or recyclable waste is soiled by the juice of household waste or mixed with the fines: this is the case for organic waste. Source separation projects fail because of the lack of separate collection and transport. Besides, when sorting is carried out in sorting stations, the issue of outlets arises. Indeed, huge quantities of 
plastic waste and sorted paper/cardboard are piled up in these stations. The last challenge highlighted by this study is the implementation of costly landfills. These facilities include sealing barriers made of compacted clay layers, geomembrane, and systems for leachate recovery and treatment. However, the large amount of low-density plastic waste in the landfill compromises rainwater infiltration by capillary action. On some sites, the leachate resurgence has been observed, preventing the optimization of the compaction of the mass of waste stored in the landfill cell. The leachate recovery and treatment system then remains unused after 2 to 4 years of operation and might be in a degraded state. Considering the obtained results (chemical analyses in the lab), the question may arise as to the relevance of these watertight barriers which should consider local conditions. Additionally, for SWM from transportation to landfill, some recommendations should be implemented in the context of cities in sub-Saharan Africa:

(a) Establish an effective source sorting system and a separate collection ;

(b) Do not collect household waste with waste from small industrial units such as garages;

(c) Landfills should be adapted to the types of waste and economize on leachate collection and treatment systems. For the installation sealing, clay can be compacted at $10-6 \mathrm{~m} / \mathrm{s}$ to a thickness of 1 meter. And then, landfills should be kept away from any sensitive areas such as flood areas, groundwater catchment areas during operation.

Acknowledgement The authors would like to thank Prof. Gnon BABA from sanitation, water and environmental sciences laboratory of Kara University in Togo for supporting data collection in Kara and thank the MSc students Seraphin N'TSULE and Aicha ZONGO who assisted in conducting the fieldwork in Kara and Ouagadougou.

\section{REFERENCES}

Abdelgadir, A., Elzaki, M., Elhassan, B., Elzaki, A., (2019). Quantification and Characterization of Solid Waste in Alkalakla Administrative Unit, Khartoum State-Sudan. Int J Waste Resour 9: $364 \mathrm{https} / / /$ doi.org/10.4172/2252-5211.1000364

Achankeng, E. (2003) Globalization, Urbanization, and Municipal Solid Waste Management in Africa. Presented at the African studies Organization of Australasta and the Pacific 2003 Conference proceeding - Africa on a global stage, p. 22.

Adebiyi-Abiola, B., Assefa, S., Sheikh, K., García, J.M. (2019) Cleaning up plastic pollution in Africa. Science 365, 1249-1251. https://doi.org/10.1126/science.aax3539

ADEME. (2014) Guide pour la réalisation de campagnes de caractérisation des déchets ménagers.
ADEME. (2006) Campagne nationale de caractérisation des ordures ménagères: Choix des catégories et des sous catégories pour l'analyse de la composition des déchets. ADEME 4.

Agence Belge de Développement, 2017. (https://www.enabel.be/fr/publication).

World Bank (2011) Urban Environmental Analysis (No. 60788ML). World Bank, Mali.

Brennan, R.B., Healy, M.G., Morrison, L., Hynes, S., Norton, D., Clifford, E. (2016) Management of landfill leachate: The legacy of European Union Directives. Waste Management 55, 355-363. https://doi.org/10.1016/j.wasman.2015.10.010

Bundhoo, Z.M.A. (2018) Solid waste management in the least developed countries: current status and challenges faced. Journal of Material Cycles and Waste Management 20, 1867-1877. https://doi.org/10.1007/s10163-018-0728-3

Burnley, S.J. (2007)a. A review of municipal solid waste composition in the United Kingdom. Journal of Waste Management 27, 1274-1285 doi.org/10.1016/j.wasman.2006.06.018

Burnley, S.J. (2007)b. The use of chemical composition data in waste management planning - A case study. Waste Management 27, 327-336. https://doi.org/10.1016/j.wasman.2005.12.020

Demakoye, V., Kone, M., Ouattara, Y., Seydou, G., Siméon, S. (2017) Evaluation of the Quality of Household Waste Leachate Treated by Settling Ponds at the Ouagadougou Waste Treatment and Valorization Center. Journal of Environmental Protection 08, 1567-1582. https://doi.org/10.4236/jep.2017.812096

DNACPN (2017) Etude de collecte et de traitement des eaux usées et des déchets solides dans 46 villes du Mali - 1ère tranche (11 villes) - Phase B: Rapport d'avant-projet détaillé stratégie de gestion des déchets solides de Koulikoro. Ministère de l'environnement, de l'Assainissement et du Développement Durable, Mali.

Guerrero, L.A., Maas, G., Hogland, W. (2013) Solid waste management challenges for cities in developing countries. Waste Management 33, 220-232.

Haro, K., Ouarma, I., Nana, B., Bere, A., Koulidiati, J. (2018) Characterization and Potential Recovery of Household Solid Waste in the City of Ouagadougou (Burkina Faso). Journal of Environmental Protection 09, 309-324. Doi:10.4236/jep.2018.94021

IGIP (2018) Detailed Pre-Project Report / Sanitation Component In Atakpamé and Dapaong - Final version (Study report), FED / 2015/366 - 217. Togo.

INSTAT (2011) $4^{\text {th }}$ General Population and Housing Census of Mali (RGPH) - Final results. Ministry of Economy and Finance. http://www.instat-mali.org/.

Koledzi, E. (2011) Valorisation des déchets solides urbains dans les quartiers de Lomé (Togo): approche méthodologique pour une production durable de compost. $\mathrm{PhD}$ thesis $\mathrm{N}^{\circ} 04$ - 2011). University of Limoges, France.

Kuleape, R., Cobbinah, S.J., Dampare, S.B., Duwiejuah, A.B., Amoako, E.E., Asare, W. (2014) Assessment of the energy recovery potentials of solid waste generation in Akosombo, Ghana. African Journal of Environmental Science and Technology 8 (5), 297-305.

Maléki, B., Gnon, B., Kwamivi, S. (2018) Quantification of Household Solid Waste in the City of Kara and Scenarization of Management. European Journal of Scientific Research 148 №2, 179-187.

Mas, S., Vogler, C. (2006) Solid waste management in Ouagadougou. (Internship report.). CREPA, Ouagadougou, Burkina Faso.

Medina, M. (1999) Globalization, Development, and Municipal Solid Waste Management in Third World Cities. Tijuana, The College of North Fronera. 
Mien, H. (2009) Etude de potentialité biogaz des déchets solides urbains dans un centre d'enfouissement technique (CET) situé en zone sahélienne : cas du CET de la ville de Ouagadougou. MSc thesis, Institut International d'Ingénierie de l'Eau et de l'Environnement (2IE), Ouagadougou, Burkina Faso.

Miezah, K., Obiri-Danso, K., Kádár, Z., Fei-Baffoe, B., Mensah, M.Y. (2015) Municipal solid waste characterization and quantification as a measure towards effective waste management in Ghana. Waste Management 46, 15-27. Doi: 10.1016/j.wasman.2015.09.009

Ministry of Ecological and Solidarity Transition, 2003. Decision $n^{\circ}$ $2003 / 33$ / CE of 12/19/02 establishing criteria and procedures for the admission of waste to landfills, in accordance with article 16 and with 'Annex II of Directive 1999/31 / EC.

Ministry of the Environment, Energy, and the Sea in charge of international relations on climate, 2016. Order of 15 February 2016 relating to storage facilities for non-hazardous waste. NOR: DEVP1519168A.

Naminata, S., Kwa-Koffi, K., Kouassi, A.M., Marcellin, Y. (2018) Assessment and Impact of Leachate Generated by the Landfill City in Abidjan on the Quality of Groundwater and Surface Water (M'Badon Bay, Côte d'Ivoire). Journal of Water Resource and Protection 10, 145-165. Doi:10.4236/jwarp.2018.101009

Ngahane, L.E., Ukondalemba Mindele, L., Nsavyimana, G., Bigumandondera, P., Vasel, J.-L., Ngnikam, E. (2015) Analyse comparative des résultats de caractérisation d'ordures ménagères : cas des communes de Bembéréké (Bénin), Kinama (Burundi), Gombe et Kimbanseke (RDC). Déchets Sciences et Techniques 69. Doi: $10.4267 /$ dechets-sciences-techniques. 3180

Ngnikam, E., Naquin, P., Oumbe R, Djietcheu B. (2017) Évolution des caractéristiques des déchets solides ménagers dans la ville de Yaoundé au Cameroun. Revue scientifique et technique forêt Et environnement du bassin du congo 8, P 45-56.

Nshimirimana, F. (2010) Caractérisation des déchets solides ménagers: cas de l'arrondissement de Sig-Noghin. MSc thesis, Institut International d'Ingénierie de l'Eau et de l'Environnement (2IE), Ouagadougou, Burkina Faso.

Oben, M., Boum, A., Besack, F. (2019) Influence of the Composition of the Municipal Solid Waste (MSW) on the Physicochemical Parameters of Leachate at the Municipal Solid Waste Landfill in Nkolfoulou -Yaounde. Current Journal of Applied Science and Technology 1-8. Doi:10.9734/cjast/2019/v33i530092

Ololade, O.O., Mavimbela, S., Oke, S.A., Makhadi, R. (2019) Impact of Leachate from Northern Landfill Site in Bloemfontein on Water and Soil Quality: Implications for Water and Food Security.

Sustainability 2019, 11(15),4238; https://doi.org/10.3390/su1115 $\underline{4238}$

Ouédraogo, A.M. (2010) Tri et collecte sélective des déchets solides de la ville de Ouagadougou: Cas du projet stratégique de réduction des déchets de Ouagadougou. MSc thesis, Université de Ouagadougou, Ouagadougou, Burkina Faso.
Pariatamby, A., Shahul Hamid, F., Bhatti, M.S. (2019) Sustainable Waste Management Challenges in Developing Countries, Steps in Environmental Engineering, and Green Technologies. IGI Global. Doi:10.4018/978-1-7998-0198-6

Safaa M. Raghab, Ahmed M. Abd El Meguid \& Hala A. Hegazi. (2013) Treatment of leachate from municipal solid waste landfill. $\begin{array}{llll}\text { HBRC } & \text { Journal } & \text { 9, } & 187-192 .\end{array}$ https://doi.org/10.1016/j.hbrcj.2013.05.007

Rothenberger, S., Zurbrügg, C., Enayetullah, I., Maqsood Sinha, A.H.M. (2006) Decentralized composting for cities of low- and middle-income countries. A users manual. EAWAG, Dhaka, Bangladesh; Dübendorf.

Segbeaya, K.N (2012) Assessment of the impact of household waste in the city of Kara (Togo) on the quality of the Kara river. PhD thesis, University of Limoges, France.

Sujauddin, M., Huda, M.S., Rafiqul Hoque, A.T.M. (2008) Household solid waste characteristics and management in Chittagong, Bangladesh. Journal of Waste Management 28, 1688-1695.

Tchakpa, C., Edorh, P.A., Guedenon, P., Boko, M. (2013) Characterization and valuation of the domestic solid waste of fidjrosse District in Cotonou (Republic of Benin) by aerobic composting. Nature Environment and Pollution Technology 12, 383-390.

Tezanou, J., 2003. Evaluation environnementale et technique de la gestion des déchets ménagers de Ouagadougou: Schéma de gestion et expérimentation de traitement thermique. $\mathrm{PhD}$ thesis, University of Poitiers, France.

Thonart, P., Diabaté, S.I., Hiligsmann, S., Lardinois, M. ( 2005) Guide pratique sur la gestion des déchets ménagers et des sites d'enfouissement technique dans les pays du sud, Collection Points de repère, ISBN 2-89481-030-X. Les publications de l'IEPF, Canada.

Topanou, N., Domeizel, M., Fatombi, J., Gérard Josse, R., Aminou, T. (2011) Characterization of Household Solid Waste in the Town of Abomey-Calavi in Benin. Journal of Environmental Protection, 2 No. 6, 2011, pp. 692-699. Doi: 10.4236/jep.2011.26080.

Troschinetz, A.M., Mihelcic, J.R. (2009) Sustainable recycling of the municipal solid waste in developing countries. Waste Management 29, 915-923. https://doi.org/10.1016/j.wasman.2008.04.016

Wilson, D.C., Velis, C., Cheeseman, C. (2006) Role of informal sector recycling in waste management in developing countries. Habitat International 30, 797-808. https://doi.org/10.1016/j.habitatint.2005.09.005

Yamadje, A., Edorh, P., Aina, M., Gnandi, K., Christophe, H., Boko, M., Tougan, U.P., 2013. Characterization of the household solid waste of the municipality of Abomey-Calavi in Benin. E3 Journal of Environmental Research and Management 4 (11), 0368-0378.

Yiougo, L.S.A., Oyedotun, T.D.T., Some, C.Y.C., Da, E.C.D. (2013) Urban cities and waste generation in developing countries. Journal of Urban and Environmental Engineering 7, 280-285. 